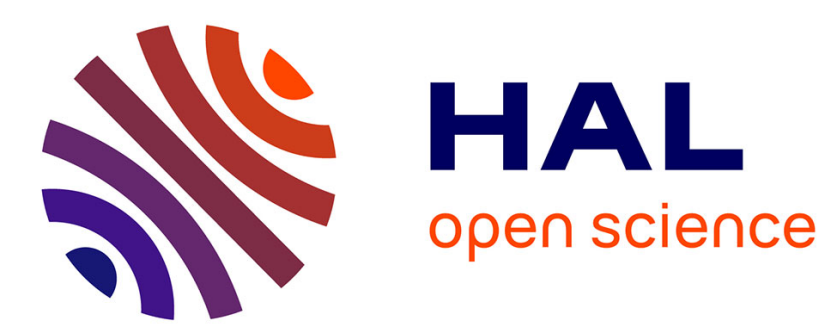

\title{
A skull of Machairodus giganteus (Felidae, Mammalia) from the Late Miocene of Turkey
}

Denis Geraads, Tanju Kaya, Vahdet Tuna

\section{To cite this version:}

Denis Geraads, Tanju Kaya, Vahdet Tuna. A skull of Machairodus giganteus (Felidae, Mammalia) from the Late Miocene of Turkey. Neues Jahrbuch für Geologie und Paläontologie Monatshefte, 2004, 2004 (2), pp.95-110. halshs-00009759

\section{HAL Id: halshs-00009759 \\ https://shs.hal.science/halshs-00009759}

Submitted on 24 Mar 2006

HAL is a multi-disciplinary open access archive for the deposit and dissemination of scientific research documents, whether they are published or not. The documents may come from teaching and research institutions in France or abroad, or from public or private research centers.
L'archive ouverte pluridisciplinaire HAL, est destinée au dépôt et à la diffusion de documents scientifiques de niveau recherche, publiés ou non, émanant des établissements d'enseignement et de recherche français ou étrangers, des laboratoires publics ou privés. 


\title{
A skull of Machairodus giganteus (Felidae, Mammalia) from the Late Miocene of Turkey
}

Denis GerAADS - UPR 2147 CNRS, 44 rue de l'Amiral Mouchez, 75014 PARIS, France dgeraads@ivry.cnrs.fr

Tanju KAYA - Ege Universitesi, Tabiat Tarihi Muzesi, 35100 BornOVA-IZMIR, Turkey tanju@sci.ege.edu.tr Vahdet TUNA - Ege Universitesi, Tabiat Tarihi Muzesi, 35100 BoRnOVA-IZMIR, Turkey

Key-words : Mammalia, Felidae, Machairodus, Late Miocene, Turkey, phylogeny, cladistics.

\begin{abstract}
A skull and associated mandible from the upper level of Kemiklitepe in Turkey is one of the most complete known specimens of Machairodus. It is distinctly more derived than specimens from the lower level. Cladistic analysis of this genus does not allow recognition of well-defined clades, but suggests instead gradual acquisition of the cranial and dental specializations that characterise Homotherium.
\end{abstract}

Zusammenfassung: Ein Schädel und der dazu gehörende Unterkiefer aus der Oberschicht von Kemiklitepe in der Türkei gehören zu den vollständigsten bekannten Exemplaren von Machairodus.

Sie erweisen sich als bedeutend höher entwickelt als die Exemplare aus der unteren Schicht. Die kladistische Analyse dieser Gattung lässt keine gut bestimmte Kladen erkennen ; sie weist viel mehr auf ein allmähliches Erwerben der Schädel- und Zahnspezialisierungen hin, die Homotherium kennzeichnen.

\section{Introduction}

The site of Kemiklitepe (meaning "the hill of bones"), in Western Turkey, was discovered by Yalcinlar in 1946. The main field collection there was made in $1989-1990$ by SEN and co-workers (SEN, 1994). They recognised (BONIS et al., 1994) two main stratigraphic units, an upper level KTA-KTB yielding a fauna of MN 12-equivalent age, and a lower level, KTD, perhaps of MN 11-equivalent age. The Carnivores collected by SEN et al. were studied by BoNIS (1994). The only carnivore described from the lower level (KTD) is a fragment of skull with incomplete mandible, that BoNIS referred to Machairodus aphanistus, but the genus was not mentioned from the upper level (KTA-KTB).

However, before the campaign led by SEN, some specimens had been collected by various workers. Some of them are housed in Musée Guimet, Lyon, but most are in the Museum of the University of Izmir. Among the latter is the skull described here, which had not been reported previously. It is numbered UEK-124 and was collected by Feral ARSLAN in 1991 in the upper part of the section (level KTA-KTB), and is therefore more recent than the one described by BoNIS (1994).

In the following descriptions, measurements are in millimetres; uppercase denotes upper teeth, lower case denotes lower teeth. 


\section{Systematic description}

Family Felidae GRAY, 1821

Genus Machairodus KAUP, 1833

Machairodus giganteus (WAGNER, 1848)

The skull is relatively well preserved, especially its left side. The main missing parts are the inner orbit, palate, and most of the premaxillae and most of the bulla. Still, it is one of the most complete and best preserved Machairodus skulls known (Fig.1).

The dorsal profile forms a gently convex curve from the nasal aperture to the missing top of the lambdoid crest. The temporal lines meet a short distance behind the orbits, and make up a high sagittal crest. The frontal is almost flat between the orbits. A hole in its central part, made prior to fossilisation, was the centre of a blow that also produced radial cracks in the whole frontal area. It was likely responsible for the death of the animal, but its origin remains unknown.

In lateral view, the dorsal profile rises steeply, so that the missing rear part of the sagittal crest is much elevated above the occlusal line. The root of the canine bulges out on the maxilla. It forms, together with the crown of the tooth, a regular curve whose extension would pass through the middle of the orbit. The posterior border of the root of the zygoma rises vertically behind the teeth, under the post-orbital process of the jugal. Thus, the orbit, being mostly above the teeth, is rather anterior. Behind it, the zygomatic arch, short and strongly built, is oriented antero-posteriorly, parallel to the tooth-row, forming a gentle arch. In lateral view, the glenoid cavity is at the same level as the lower border of the zygomatic arch, thus much higher than the tooth-row. The post glenoid process is of moderate size. The posterior face of the zygomatic arch is vertical. Behind the external auditory meatus, the mastoid process (Fig.2A) assumes the shape of a rectangle directed obliquely downwards and forwards; thus, it is convergent downwards with the posterior face of the zygomatic arch. The paroccipital process, short and spine-shaped, pressed against the posterior face of the bulla, is directed posterolaterally, and is thus perpendicular to the mastoid rectangle. It is strongly protruding backwards, and a deep notch separates it from the condyle. The masseter insertion on the zygomatic arch is poorly defined. It does not reach the maxilla. The zygomatic arches are less broad than in Panthera, indicating more reduced temporal muscles. The occipital area, high and narrow, is limited laterally by the occipital crest and is heavily sculptured.

The basicranial area, well preserved on the left side, is the most interesting part of the skull (Fig.2B, C). The posterior border of the pterygoid flange is at the level of the glenoid fossa, thus more posterior than in modern Felids, and it is also more vertical. The oval foramen is directed anteriorly and much less ventrally than in modern Felids, as noted by BoNIS (1994). On both sides of the area between it and the foramen rotundum are small cliff-like elevations which doubtless represent remnants of the alisphenoid canal, completely lost in modern Felids, but still present on the specimen from the lower level of Kemiklitepe (BONIS, 1994). The roof of the canal seems to have been missing in life, rather than broken after death. The petro-tympanic suture is no longer traceable, perhaps because of the old age of the animal. The antero-ventral part of the bulla is flattened behind the middle lacerate foramen so that the inflated part of the bulla is restricted to the area behind the external auditory meatus. Most of the bulla is broken 
away. An internal ridge along the mastoid might represent a remnant of a septum dividing the bulla, as in the specimen from the lower level (BoNIS, 1994), but the internal part of the bulla is not preserved in our specimen. The glenoid foramen opens in the same position as in modern Felids. The basioccipital is very broad, especially in its middle part; the anterior tuberosities are large and rough, but not prominent, and the bone is depressed behind them, on both sides of a sagittal crest. The condylar foramen is well distinct from the posterior lacerate foramen, as on the specimen from the lower level.

The right upper canine is well preserved. It is of moderate size, so that even with the jaws closed, its tip did not reach the level of the lower border of the mandible. Both its anterior and posterior edges are regularly curved. The posterior keel is blunted by use, and the anterior edge is smoothed in its lower part, probably by wear against the lower canine. About two centimetres below the alveolar level, the anterior keel turns inward and fades out. The crosssection of the canine is symmetrical, with a rounded anterior edge and a sharper posterior one. There is no indication whatever of an anterior or lateral flattened or depressed area.

There is no $\mathrm{P} 2$, and a short diastema separates the canine from $\mathrm{P} 3$, which is badly broken anteriorly. The posterior part is well preserved, although the lingual expansion is worn. The posterior cingulum is reduced, and not expanded labially. P4 is so heavily worn that its length cannot be precisely given. Nothing is visible of the blade morphology, but a strong root protrudes lingually, indicating that a small but distinct protocone was present, although its is now completely abraded.

An alveolus shows that a M1 was present, but its size cannot be estimated.

The lower jaw is only partly preserved. It includes the symphysial area, except its basal part, with all front teeth, a part of the right corpus with the premolars, and the posterior part of the left one, with the coronoid apophysis. Both carnassials are missing.

The corpus mandibularis is of regular depth, being only slightly deeper anteriorly (Fig.3A). In lateral view, the lower border is gently concave at the level of p3, indicating that the antero-inferior area was angular rather than rounded, but there is no indication of mental apophysis. The posterior mental foramen opens below the anterior root of $\mathrm{p} 3$.

The coronoid apophysis is high and narrow, not much more reduced than in Panthera.

All teeth are imperfectly preserved, and most of them are much worn. None of them bears any trace of crenulation. All incisors are set more anteriorly than the canines, so that most of $\mathrm{i}$, including its root, is visible laterally. They form a wide arch in upper view (Fig.3B), increase in size from i1 to i3, and diverge upwards in front view. Their morphology is obscured by wear and imperfect preservation.

The canines are also set wide apart (the distance between them and the midline is much greater than their thickness) and they diverge upwards. There is no evidence of crenulation, but there is a clear, although small, wear facet for 13 , and probably a small one for the upper canine. In any case, antagonism between the canines was greatly reduced, and of weak functional significance. The diastema is of normal length $(35 \mathrm{~mm})$. There is no p2, as usual in this group. The $\mathrm{p} 3$ is broken and imperfectly preserved, but is unworn. It is low, with a weak anterior tubercle, and is closely pressed against $\mathrm{p} 4$. The latter has a strong anterior tubercle, whose long antero-posterior axis is slightly angled in respect to the tooth-row. 
Measurements

$\begin{array}{lccccccccc} & \text { I3 } & \text { C } & \text { P4 } & \text { i1 } & \text { i2 } & \text { i3 } & \text { C } & \text { p3 } & \text { p4 } \\ \text { Length } & 11.8 & 29.9 & 39+ & 4.3 & 6.2 & 7.8 & 15.0 & 18.5 & 27.2 \\ \text { Width } & 9.5 & 13.3 & - & 6.8 & 8.7 & 9.2 & 11.1 & 7.5 & 11.2+\end{array}$

Width over P4s = ca. 102

Maximum width over orbits $=115$

Minimum post-orbital width $=66$

Width of brain-case $=79$

From I3 to posterior border of glenoid $=203$

Length condylo-I $3=277$

From orbit to front of crown base of $C=107$

Length of mandibular diastema $=$ ca. 32

Depth of corpus below diastema $=38.2$

Maximum depth at coronoid process $=82$

\section{Cladistic analysis}

In order to determine the phyletic relationships of the Machairodus from Kemiklitepe, we have performed a parsimonious cladistic analysis on 33 OTUs, most of them representing single specimens, or in a few cases small samples from very close localities. The cladogram is rooted by adding two outgroups with hypothetical ancestral states.

We used 22 characters, either discrete or metric. For the latter ones, we calculated the mean $M$ and standard deviation $S$, and coded the character states as follows: $x>M+S: 0 ; M$ $+S<x<M: 1 ; M<x<M-S: 2 ; x<M-S: 3$. We used ratios for most measurements, to avoid scale factor, but we have not attempted any allometric analysis. Given the relatively limited size range, and poor correlations, it would not be very significant. All characters are treated as additive.

Several other characters are in fact metric but cannot be precisely measured, and are treated as discrete. We have not used all of the characters often mentioned in the literature. Some of them are autapomorphic, or at least look autapomorphic because they can seldom be observed. We have not used canine wear, because lack of wear can just be due to young ontogenic age. We have not used enamel crenulations either, because they are often obscured by wear. Skull proportions would probably yield interesting results, but there are so few uncrushed skulls that reliable metric data are almost lacking.

The list of references, definition of character states and matrix are given in the appendix.

The parsimonious cladistic analysis yielded a single shortest tree $(87 \mathrm{steps}, \mathrm{ci}=51$, $\mathrm{ri}=$ 76; Fig.4). The many missing data in the matrix, and the great intraspecific variability of machairodonts, already noticed by several authors, especially BEAUMONT (1975) certainly account for the lack of well defined groups. Rather different cladograms can be obtained by increasing only marginally the length of the tree, and the one shown in Fig.4 should be regarded as a mere tentative proposal.

The lower branches of the tree can be united in a paraphyletic group that could be called Machairodus aphanistus. M. alberdiae from Los Valles is close to the poorly known M. robinsoni from Bled Douarah in Tunisia, as noted by GINSBURG et al. (1981), but both can be included in the group of M. aphanistus. As suggested by BoNIs (1994), M. pseudaeluroides from 
Akçaköy can be included here, although its strongly compressed upper canine is an unexpected derived feature here. All these forms are of Vallesian or Vallesian-equivalent age. Interestingly, the specimen from Kemiklitepe D (BONIS, 1994) branches immediately higher, lending support both to its specific identification and to the early Late Miocene age of this level, but its position might well be partly due to the lack of upper teeth, upon which most of this part of the cladogram is based.

Leaving aside the poorly described specimen from Grebeniki, the following branches reflect the progressive acquisition of the derived traits that characterise M. giganteus. These include larger size (reflected in a larger p4), a shorter P3, which later also becomes narrower (except in Greece), reduction of the protocone of $\mathrm{P} 4$, which becomes relatively longer through addition of a preparastyle, further reduction of M1, reduction of the lower canine in respect to the incisors or $\mathrm{m} 1$, and a stronger anterior cuspid on $\mathrm{p} 4$. Cranial features are almost unknown in M. aphanistus, but reduction of the alisphenoid canal and strengthening of the zygomatic arches probably occurred here.

In higher branches, advanced dental features include shortening of $p 3$, followed by shortening of $\mathrm{P} 3$, increase of shearing specialisations of the carnassials, with the loss of $\mathrm{m} 1$ talonid, reduction of P4 protocone, and secondary reduction of the anterior cuspid of $\mathrm{p} 4$ in the highest branches. At the same time, changes in skull architecture occurred too, but are difficult to figure precisely, as there are too few well preserved skull. The zygomatic arch becomes more curved, the mastoid process longer and the glenoid cavity lowered in respect to the auditory foramen, and the orbit is farther from the canine. Significant new results could probably be provided by 3-D analysis, but would require direct access to several not deformed skulls.

Unambiguous taxonomic results are few. The specimen UEK-124 clearly falls among the specimens usually referred to $M$. giganteus, but it is hard to provide a diagnosis of this species. The same is true of the genus Homotherium, and this explains why the generic attribution of several specimens has been disputed (Fan Tsun, Aïn Brimba). The skull from Fan Tsun, said to be of Pleistocene age, branches rather low on the tree, which would be of better agreement with an earlier age, as surmised by PETTER \& HOWELL (1987). The skulls from Halmyropotamos and ravin X look misplaced, but have a narrow P4, like Homotherium, which form the last group. It consists of the six highest branches, which have been referred to as many species. Better estimates of intra-specific variability are needed before this can be accepted.

\section{Acknowledgements}

D.G. thanks Mrs MAMITU YILMA and P. TASSY for giving access to collections housed in the National Museum of Ethiopia, Addis Abeba, and in the Muséum National d'Histoire Naturelle, Paris, respectively. Travels grants were provided by the CNRS. 


\section{References}

Arambourg, C \& Piveteau, J. (1929). Les Vertébrés du Pontien de Salonique. - Annales de

Paléontologie, 18: 1-82.

BALLESIO, R. (1963): Monographie d'un Machairodus du gisement villafranchien de Senèze: Homotherium crenatidens FABRINI. - Travaux du laboratoire de

Géologie de la faculté des sciences de Lyon, N.S. 9: 1-129.

BEAUMONT, G. DE (1975): Recherches sur les Félidés (Mammifères, Carnivores) du Pliocène inférieur des sables à Dinotherium des environs d'Eppelsheim. Archives des Sciences, 28 (3): 369-405.

BEAUMONT, G. DE (1987): Note sur deux nouvelles dents de Machairodus aphanistus (KAUP) Mammifère carnivore du Vallésien des Sables à Dinotherium de Rheinhessen. - Archives des Sciences, 40 (2): 225-229.

BEAUMONT, G. DE (1988): Contributions à l'étude du gisement miocène supérieur de Montredon (Herault). Les grands mammifères. 2 Les Carnivores. -

Palaeovertebrata, Mémoire extraordinaire, 15-42.

BEAumONT, G. DE \& CRuSAFONT-PAIRO, M. (1982): Les Félidés (Mammifères, Carnivores) du Vallésien du Vallès, Catalogne, Espagne. - Archives des Sciences, 35 (1): 41-64.

BONIS, L. DE (1976): Un Félidé à longues canines de la colline de Perrier (Puy-deDôme): ses rapports avec les Félidés machairodontes. - Annales de Paléontologie (Vertébrés), 62 (2): 159-198.

BONIS, L. DE (1984): Nouvelles données sur les Félinés machairodontes: un Homothère du Quaternaire moyen de la région de Vérone (Italie). Actes du symposium Cuvier, Montbéliard, p.27-33.

BONIS, L. DE (1994): Les gisements de Mammifères du Miocène supérieur de Kemiklitepe, Turquie. 2: Carnivores. - Bulletin du Muséum National d'Histoire Naturelle, 4ème sér., C, 16: 19-39.

Bonis, L. De, Bouvrain, G., GeraAds, D., Koufos, G., Sen, S. \& TAssy, P. (1994): Les gisements de Mammifères du Miocène supérieur de Kemiklitepe, Turquie. 11: Biochronologie, paléoécologie et relations paléobiogéographiques. - Bulletin du Muséum National d'Histoire Naturelle, 4ème sér., C, 16: 225-240.

CHANG HSI-CHIH, (1957): On new material of some machairodonts of Pontian age from Shansi. -Vertebrata PalAsiatica, 1 (3): 193-198.

GinsbuRG, L., MoRAles, J. \& SoriA, D. (1981): Nuevos datos sobre los carnivoros de los Valles de Fuentidueña (Segovia). - Estudios geológicos, 37 (5-6): 383-415.

HENDEY, Q. B. (1974): The late Cenozoic Carnivora of the south-western Cape province. - Annals of the South African Museum, 63: 1-369.

KouFOS, G. D. (2000): Revision of the late Miocene carnivores from the Axios valley, Macedonia, Greece. - Münchener Geowissenschaftliche Abhandlungen, 39: 5192. 
KURTEN, B. (1976): Fossil Carnivora from the Late Tertiary of Bled Douarah and Cherichira, Tunisia. - Notes du Service géologique de Tunisie, 42: 177-214.

MELENTIS, J.K. (1967): Studien über fossile Vertebraten Griechenlands. 19. Die

Pikermifauna von Halmyropotamos (Euböa, Griechenland). - Annales géologiques des pays helléniques, 19: 283-411.

MORALES, J. \& SoRIA, D. (1979): Nuevos datos sobre los carnívoros del área de Teruel. Síntesis y biostratigrafía. - Estudios geológicos, 35: 497-504.

ORLOV, J. A. (1936): Tertiäre Raubtiere des Westlichen Sibiriens. I. Machairodontinae.Travaux de l'Institut de Paléozoologie, Académie des Sciences d'URSS. - 5: 111-152.

PAVLoW, M. (1914): Mammifères tertiaires de la nouvelle Russie. $2^{\text {ème }}$ partie. Aceratherium incisivum, Hipparion, Proboscidea, Carnivora. 17 (4): 1-52.

PetTer, G. \& Howell, F.C. (1987): Machairodus africanus ARAmbouRg, 1970 (Carnivora Mammalia) du Villafranchien d'Aïn Brimba, Tunisie. - Bulletin du Muséum National d'Histoire Naturelle, $4^{\text {ème }}$ sér., C, 9 (1): 97-119.

PetTer, G. \& Howell, F.C. (1988): Nouveau Félidé Machairodonte (Mammalia, Carnivora) de la faune pliocène de l'Afar (Ethiopie): Homotherium hadarensis n.sp. - Comptes Rendus de l'Académie des Sciences, II, 306: 731-738.

RIABININ, A. (1929): Faune de Mammifères de Taraklia. Carnivora vera. Rodentia. Subungulata. - Travaux du Musée Géologique de l'Académie des Sciences d'URSS, 5: 127-134.

SCHMIDT-KITTLER, N. (1976): Raubtiere aus dem Jungtertiär Kleinasiens. Palaeontographica, A, 155: 1-131.

SEN, S. (1994): Les gisements de mammifères du Miocène supérieur de Kemiklitepe, Turquie. - Bulletin du Muséum National d'Histoire Naturelle, 4ème sér., C, 16: 1240.

SENYÜREK, M.S. (1957): A new species of Epimachairodus from Kücükyozgat. - Türk Tarih Kurumu Belleten, 21 (81): 1-60.

SOTNIKOVA, M. V. (1992): A new species of Machairodus from the late Miocene Kalmakpai locality in eastern Kazakhstan (USSR). - Annales zoologici Fennici, 28: 361-369.

TEILHARD de CHARDIN, P. (1939): On two skulls of Machairodus from the lower Pleistocene beds of Choukoutien. - Bulletin of the Geological Society of China, 19 (3): 235-256.

Teilhard de Chardin, P. \& Piveteau, J. (1930): Les mammifères fossiles de Nihowan (Chine). - Annales de Paléontologie, 19: 1-134.

YALÇINLAR, I. (1946): Une faune de vertébrés miocènes aux environs d'Esme (Turquie, vallée du Méandre supérieur). - Revue de la Faculté des Sciences d'Istanbul, B, 11 (2): 124-130.

ZDANSKY, O. (1924): Jungtertiäre Carnivoren Chinas. - Palaeontologia Sinica, C, 2, 1: 1149. 


\section{Captions to Figures}

Fig.1. The skull of Machairodus giganteus from Kemiklitepe UEK-124. A: lateral view; B: upper view. Scale $=10 \mathrm{~cm}$.

Fig.2. Skull UEK-124. A: lateral view of auditory region; 2: ventral view of skull base, stereo pair; C: ventro lateral view of skull base, stereo pair; the arrows point to the remnants of the alisphenoid canal. Scale $=5 \mathrm{~cm}$.

Fig.3. Mandible UEK-124. A: lateral view; B: dorsal view. Scale $=5 \mathrm{~cm}$.

Fig.4. The shortest tree. 
The 33 OTUs used in the cladistic analysis, roughly listed by age. The numbers refer to those of the matrix.

$\begin{array}{ll}\mathbf{1} & \text { Bled Douarah } \\ \mathbf{2} & \text { Los Valles } \\ \mathbf{3} & \text { Can Llobat., Santiga } \\ \mathbf{4} & \text { Charmoille } \\ \mathbf{5} & \text { Eppelsheim } \\ \mathbf{6} & \text { Akçaköy } \\ \mathbf{7} & \text { Montredon } \\ \mathbf{8} & \text { Kemiklitepe D } \\ \mathbf{9} & \text { Mahmutgazi } \\ \mathbf{1 0} & \text { Küçükyozgat } \\ \mathbf{1 1} & \text { Vathylakkos } \\ \mathbf{1 2} & \text { Grebeniki } \\ \mathbf{1 3} & \text { Kemiklitepe A-B } \\ \mathbf{1 4} & \text { Taraklia } \\ \mathbf{1 5} & \text { Samos } \\ \mathbf{1 6} & \text { Pavlodar } \\ \mathbf{1 7} & \text { Halmyropotamos } \\ \mathbf{1 8} & \text { MN 12/13, Spain } \\ \mathbf{1 9} & \text { Loc. 113 } \\ \mathbf{2 0} & \text { Kalmakpai } \\ \mathbf{2 1} & \text { Loc.30 } \\ \mathbf{2 2} & \text { Loc.30 } \\ \mathbf{2 3} & \text { Yushe, Shansi } \\ \mathbf{2 4} & \text { Baode, Shansi } \\ \mathbf{2 5} & \text { Langebaanweg } \\ \mathbf{2 6} & \text { Aïn Brimba } \\ \mathbf{2 7} & \text { Hadar } \\ \mathbf{2 8} & \text { Roccaneyra } \\ \mathbf{2 9} & \text { Fan Tsun } \\ \mathbf{3 0} & \text { Nihowan II } \\ \mathbf{3 1} & \text { Senèze } \\ \mathbf{3 2} & \text { Zhou Kou Dian } \\ \mathbf{3 3} & \text { Verona } \\ & \end{array}$

$\begin{array}{ll}\text { Late Miocene } & \text { M. robinsoni } \\ \text { Late Miocene } & \text { M. alberdiae } \\ \text { Late Miocene } & \text { M. cf. aphanistus } \\ \text { Late Miocene } & \text { M. aphanistus } \\ \text { Late Miocene } & \text { M. aphanistus } \\ \text { Late Miocene } & \text { M. pseudaeluroides } \\ \text { Late Miocene } & \text { M. cf. aphanistus } \\ \text { Late Miocene } & \text { M. aphanistus } \\ \text { Late Miocene } & \text { M. aphanistus } \\ \text { Late Miocene } & \text { M. romeri } \\ \text { Late Miocene } & \text { M. giganteus } \\ \text { Late Miocene } & \text { Pogonodon copei } \\ \text { Late Miocene } & \text { M. giganteus } \\ \text { Late Miocene } & \text { M. aphanistus taracliensis } \\ \text { Late Miocene } & \text { M. giganteus } \\ \text { Late Miocene } & \text { M. irtyshensis } \\ \text { Late Miocene } & \text { M. aphanistus } \\ \text { Late Miocene } & \text { M. giganteus } \\ \text { Late Miocene } & \text { M. palanderi } \\ \text { Late Miocene } & \text { M. kurteni } \\ \text { Late Miocene } & \text { M. tingi } \\ \text { Late Miocene } & \text { M. palanderi } \\ \text { Late Miocene } & \text { M. tingi } \\ \text { Late Miocene } & \text { M. palanderi } \\ \text { Early Pliocene } & \text { Machairodus sp. } \\ \text { Pliocene } & \text { M. africanus } \\ \text { Late Pliocene } & \text { H. hadarense } \\ \text { Late Pliocene } & \text { H. nestianus } \\ \text { Early Pleistocene } & \text { Machairodus sp. } \\ \text { Early Pleistocene } & \text { M. nihowanensis } \\ \text { Early Pleistocene } & \text { H. crenatidens } \\ \text { Mid. Pleistocene } & \text { M. ultimus } \\ \text { Mid. Pleistocene } & \text { H. moravicum } \\ & \end{array}$

KURTÉN, 1976

GINSBURG et al., 1981

BEAUMONT \& CRUSAFONT 1982

BEAUMONT, 1975

BEAUMONT, 1975, 1987

SCHMIDT-KITTLER, 1976

BEAUMONT, 1988

BONIS, 1994

SCHMIDT-KITTLER, 1976

SENYÜREK, 1957

KoufOS, 2000

PAVLOW, 1914

this paper

RIABININ, 1936

BEAUMONT, 1975

ORLOV, 1936

MELENTIS, 1967

MORALES \& SORIA, 1979

ZDANSKY, 1924

SOTNIKOVA, 1992

ZDANSKY, 1924

ZDANSKY, 1924

CHANG, 1957

CHANG, 1957

HENDEY, 1974

PetTer \& HOWELL, 1987

PetTer \& Howell, 1988

BONIS, 1976

PetTer \& HOWELL, 1987

TEILHARD \& PIVETEAU, 1930

BALLÉSIO, 1963

TEILHARD, 1939

BONIS, 1984 
List and states of the 22 characters

\begin{tabular}{|c|c|}
\hline & \\
\hline & $W C>/ L$ \\
\hline & L P3 / LP \\
\hline & W P4 I \\
\hline & L p3 / L p4 \\
\hline & L p4 \\
\hline & $\mathrm{LC}<1$ \\
\hline
\end{tabular}

\section{non-metric characters}

6 axis of $\mathrm{C}$ root / orbit

$7 \quad$ ant. border orbit / P4

8 zygomatic arch

9 curvature zygomatic arch

10 glenoid fossa / alveolar line

11 glenoid fossa

12

13

14

15

16

17

18

19

20

21

0
very thick
P3 very long
P4 very thick
p3 very long
p4 very long
C $<$ very short

mastoid process

alisphenoid canal

condylar / post. lacerius foramina

posterior part of $\mathrm{P} 3$

preparastyle on $\mathrm{P} 4$

protocone of $\mathrm{P} 4$

size of M1

distance from /c to sagittal plane anterior cuspid of $\mathrm{p} 4$

talonid of $\mathrm{m} 1$

$\begin{array}{ccccc}\mathbf{1} & \mathbf{2} & \mathbf{3} & \text { mean } & \mathbf{S} \\ \text { thick } & \text { thin } & \text { very thin } & 0.432 & 0.056 \\ \text { P3 long } & \text { P3 short } & \text { P3 very short } & 0.479 & 0.152 \\ \text { P4 thick } & \text { P4 thin } & \text { P4 very thin } & 0.372 & 0.07 \\ \text { p3 long } & \text { p3 short } & \text { p3 very short } & 0.673 & 0.137 \\ \text { p4 long } & \text { p4 short } & \text { p4 very short } & 24.8 & 3.3 \\ \text { C< short } & \text { C < long } & \text { C < very long } & 0.568 & 0.074\end{array}$

0

anterior

rear of $\mathrm{P} 4$

weak

weak

much higher

oblique

short

present

separate

broad

absent

present

small

$<$ diameter $\mathrm{C}$

weak

present

1

2

tangential

more anterior

strong

strong

higher

transversal

medium

vestigial

merging

narrow

present

reduced

very small

\pm diameter $\mathrm{C}$

moderate

absent

through orbit

very anterior

very strong

very strong

same level

long

absent

fused

absent

$>$ diameter $\mathrm{C}$

large 
The matrix used in the cladistic analysis

\begin{tabular}{|c|c|c|c|}
\hline & & 1 & 2 \\
\hline & 0 & 0 & 0 \\
\hline Outg1 & 0001?3??00 & $0 ? 000 ? 0000$ & 00 \\
\hline Outg2 & 0001?3??00 & 0?000?0000 & 00 \\
\hline 1 & 0??13????? & ?????????? & $? 0$ \\
\hline 2 & 0??032???? & ?????0???0 & $? ?$ \\
\hline 3 & 0???2????? & ?????0100? & $0 ?$ \\
\hline 4 & 0??11????? & ?????????? & 00 \\
\hline 5 & ???113???? & ?????000?0 & 10 \\
\hline 6 & $300 ? 2 ? 12 ? ?$ & ?????0000? & 00 \\
\hline 7 & 1?1123???? & ?????010?0 & 00 \\
\hline 8 & 210122??0? & ??100?000? & $? 0$ \\
\hline 9 & ?1111????? & ?????111?? & $? 0$ \\
\hline 10 & 2??111???? & 0????111?2 & 10 \\
\hline 11 & $212 ? 0122 ? ?$ & ?????0111? & 11 \\
\hline 12 & ?1?????200 & 0?1???11?? & $? ?$ \\
\hline 13 & $11211 ? 2211$ & $011100 ? 1 ? 2$ & $1 ?$ \\
\hline 14 & ?1120?0110 & 1?1???11?2 & 21 \\
\hline 15 & ???101???? & ?????????2 & 20 \\
\hline 16 & ???101???? & ?????????? & $1 ?$ \\
\hline 17 & 212????1?? & 111??012?? & $? ?$ \\
\hline 18 & ???110???? & ?????011?? & $1 ?$ \\
\hline 19 & ?11210011? & $011 ? ? 11202$ & 11 \\
\hline 20 & 2112112100 & $112 ? 011112$ & 11 \\
\hline 21 & 2??20????? & ?????112?2 & $2 ?$ \\
\hline 22 & 312???21?? & ?????1121? & $? ?$ \\
\hline 23 & ?1110?2??? & ?????????2 & $? ?$ \\
\hline 24 & $311 ? ? ? 2110$ & 011??1?21? & $? ?$ \\
\hline 25 & 122??????? & ?????1111? & .1 \\
\hline 26 & 222???1??? & 1?2??????? & ?? \\
\hline 27 & $133 ? 1 ? 1111$ & $102 ? 11 ? 21 ?$ & $? ?$ \\
\hline 28 & 1333301012 & 2122110212 & 01 \\
\hline 29 & $111 ? ? ? 2111$ & 2?1??111?? & $? ?$ \\
\hline 30 & 23???210?? & ?????1021? & $? ?$ \\
\hline 31 & 2??32?0122 & $102201 ? 212$ & 11 \\
\hline 32 & 233????112 & $201 ? 211211$ & \\
\hline 33 & ??2?2????? & ??????12?? & ? \\
\hline
\end{tabular}

